\title{
Peranan Penyuluh Agama Islam dalam Dakwah
}

\section{Ilham}

\section{UIN Antasari Banjarmasin}

\begin{abstract}
Islam is a religion of da'wah which obliges his followers to preach according to their capabilities. Islamic instructors are part of the implementation of da'wah (da'i) guiding religious life of the people and bearers of the development mission with a religious approach to society. That is why Islamic Religion Counselors play a very important and strategic role in creating a religious, prosperous and happy society. It plays a role as a leader in religious, social and state affairs for its targets, social change agents, and motivators, facilitators and even community development catalysts.
\end{abstract}

Keywords: Islam; Da'wah; Extension.

\section{Pendahuluan}

Agama bagi umatnya adalah pedoman hidup, juga sebagai landasan spiritual, moral dan etika dalam hidup dan kehidupan. Oleh karena itu agama sebagai sistem nilai seharusnya dipahami, dihayati dan diamalkan oleh seluruh pemeluknya dalam tatanan kehidupan setiap individu, keluarga dan masyarakat serta menjiwai kehidupan berbangsa dan bernegara untuk mewujudkan masyarakat sejahteram aman stabil, dan sebagainya. Agar agama dapat tersebar luas, untuk diketahui, dipahami, dihayati dan diamalakan, maka ia harus didakwahkan.

Islam adalah agama dakwah, yakni agama yang selalu mendorong pemeluknya untuk senantiasa aktif dalam kegiatan 
dakwah, mengajak umat manusia menerima Islam serta melakukan amar ma'ruf dan nahi munkar, untuk kebahagiaan dunia dan akhirat. Sebagian dari pelaksana pendakwah atau da'i adalah penyuluh agama Islam yang melakukan dakwah dengan kegiatan bimbingan dan penyuluhan agama Islam, terutama kepada komunitas masyarakat muslim.

Penyuluh agama Islam sebagai pelaksana kegiatan penyiaran agama mempunyai peranan yang sangat strategis dalam meningkatkan kualitas kehidupan umat. Karena masalah dakwah inklusif penyuluhan agama Islam berarti membahas tentang umat dengan segala problematika, baik menyangkut kualitas kehidupan beragama maupun kesejahteraan umat. Sebab banyak kasus dan fakta dakwah betapa kemaslahatan umat (dakwah bil hal) belum terealisasi dengan baik oleh pelaksana dakwah. Padahal aspek dakwah yang berdemensi pada kesejahteraan adalah bagian yang sangat penting dalam membentengi umat dari kekufuran.

Masalah kesejahteraan umat salah satu problematika dakwah dari sisi pelaksana dakwah, dimana sebagian aktivitas dakwah belum mampu mengurai persoalan yang dihadapi umat secara rinci, untuk kemudian dicarikan solusinya dalam konteks dakwah. Ungkapan ini tidak memperkecil peran para pelaksana dakwah, Sebab, betapapun rendahnya kualitas keilmuan dan kemampuan penyampaian seorang da'i, umumnya umat Islam menyadari bahwa ia da'i, tetap merupakan pemeran utama dari gerakan dakwah. Penyuluh agama Islam merupakan unsur yang dominan dalam pelaksanaan dakwah/ penyuluhan agama Islam. Ia memegang peranan yang sangat penting terhadap sukses atau tidaknya pelaksanaan dakwah/penyuluhan agama tersebut. 
Penyuluh agama Islam sebagai pelaksana utama kegiatan penyuluhan agama Islam harus mampu merealisasikan kegiatan bimbingan dan penyuluhan agama Islam dalam masyarakat, dimanapun ia berada. Dalam tugasnya penyuluh agama Islam harus melaksanakan amar makruf dan nahi munkar harus sebagai ikhtiar mewujudkan tatanan masyarakat yang agamis, sejahtera dan bahagia.

\section{Pembahasan}

\section{Pengertian Penyuluhan Agama Islam}

Istilah Penyuluhan dalam bahasa Indonesia berakar dari kata suluh yang bermakna alat penerangan, pemberi terang di tengahtengah kegelapan (W.J.S. Poerwardarminta, 2003: 767). Kata Penyuluhan sebenarnya terjemahan dari kata dalam bahasa Inggeris to councel yang artinya memberikan nasehat atau anjuran kepada orang lain secara berhadapan muka satu sama lain. Penyuluhan diartikan pemberian nasehat atau penasehatan kepada orang lain socara individual (perorangan) yang dilakukan dengan face to face. (H.M. Arifin, 1976: 18)

Menurut Isep Zaenal Arifin (2009:50), penyuluhan adalah suatu proses pemberian bantuan baik kepada individu ataupun kelompok dengan menggunakan metode-metode psikologis agar individu atau kelompok dapat keluar dari masalah dengan kekuatan sendiri, baik secara preventif, kuratif, korektif maupun developmental, dengan cirri pokok sebagai berikut:

1. Adanya seorang atau lebih pembicara sebagai nara sumber

2. Lebih banyakmenggunakan komunikasi verbal

3. Dapat digabung dengan berbagai kegiatan

4. Bersifat Umum

5. Sasarannya Khalayak 
6. Tidak memuntut khalayak terlibat lebih jauh dalam target penyuluhan, mereka cukup mengetahui informasinya saja

7. Bersifat fleksibel, dapat dilakukan di mana saja (formal, informal, skala besar maupun kecil)

Berdasarkan lingkup ilmu dakwah istilah bimbingan penyuluhan Islam adalah Irsyad Islam. Definisi dari istilah-istilah ini dapat juga digunakan istilah-istlah ta'lim, maw'izhah, nashihah, dan isytisyfac (terapi dalam kontek psikoterapi). Istilah dari Guidance dan counseling suatu nama yang pada umumnya diberikan kepada bentuk aplikasi dari psikologi pendidikan dan dalam disiplin ilmu psikologi, guidance and counseling atau bimbingan dan penyuluhan merupakan cabang dari ilmu tersebut. Dalam bahasa arab, istilah bimbingan dan penyuluhan disebut dengan al irsyad an Nafsyi yang artinya bimbingan kejiwaan, istilah mana bisa digunakan guidance and counseling, sekaligus untuk pengertian bimbingan dan penyuluhan agama Islam. (Achmad Mubarok, 2000: 2).

Penyuluhan agama adalah proses pemberian bantuan terhadap individu agar individu dapat mengatasi kesulitan yang dihadapi, membuat pilihan yang bijaksana dalam menyesuaikan diri dan lingkungan, serta dapat membentuk pribadi yang mandiri. Agama merupakan suatu ajaran yang datang dari Tuhan yang berfungsi sebagai pembimbing kehidupan manusia agar mereka hidup bahagia dunia dan akhirat (Achmad Mubarok, 2004: 4)

Dalam konteksnya dengan agama Islam, penyuluhan agama Islam diartikan usaha penyampaian ajaran Islam kepada umat manusia oleh seseorang atau kelompok orang secara sadar dan terencana, dengan berbagai metode yang baik dan sesuai dengan 
kondisi sasaran penyuluhan, sehingga berubahlah keadaan umat itu kepada yang lebih baik, untuk memperoleh kebahagiaan di dunia dan di akhirat. Hasil akhir yang ingin dicapai dari penyuluham agama Islam pada hakekatnya ialah terwujudnya kehidupan masyarakat yang memiliki pemahaman mengenai agama Islam secara memadai yang ditunjukkan melalui pengamalannya yang penuh komitmen dan konsisten disertai wawasan multi kultural, untuk mewujudkan tatanan kehidupan yang harmonis dan saling menghargai satu sama lain.

\section{Dasar Pelaksanaan Penyuluhan Agama Islam}

Dasar penyelenggaraan penyuluhan agama Islam adalah AlQur'an dan Al-Hadits.

Dalam Surat Ali Imran ayat 104:

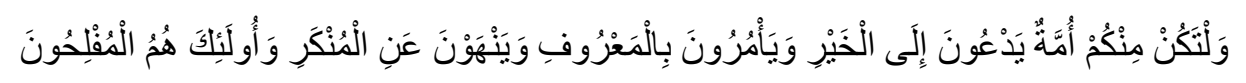

"Dan hendaklah ada diantara kamu segolongan umat yang menyeru kepada kebajikan, menyuruh kepada yang makruf dan mencegah dari yang mungkar, merekalah orang-orang yang beruntung”.

Dalam sebuah hadits, Rasulullah saw bersabda:

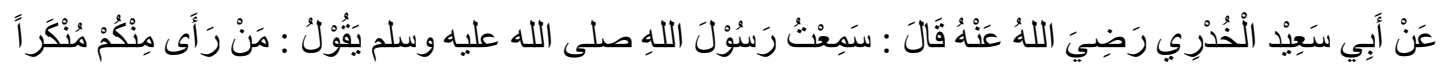

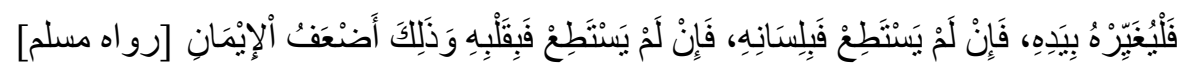

"Dari Abu Sa'id Al-Khudry r.a. berkata: Aku telah mendengar Rasulullah saw. Bersabda: Barang siapa diantara kalian melihat kemungkaran, maka hendaklah dia merubah dengan tangannya (kekuasaannya), bila tidak mampu dengan lidahnya. Bila dia tak sanggup, maka dengan hatinya dan yang demikian ini adalah tindakkan orang yang lemah imannya". 
Melaksanakan penyuluhan, yang mencakup amar makruf nahi mungkar, yaitu mengajak segala perbuatan yang dapat mendekatkan diri kepada Allah dan nahi munkar yaitu melarang segala perbuatan yang dapat menjauhkan diri dari Allah, adalah merupakan kewajiban bagi setiap muslim dan muslimat, menurut kadar kemampuan serta bidang masing-masing, agar umat manusia (masyarakat) mengerjakan segala yang diperintahkan oleh Allah dan meninggalkan laranganNya. Penyuluh Agama Islam merupakan bagian dari pelaksana dakwah yang ditugasi oleh Kementerian Agama, untuk melaksanakan kegiatan penyuluhan agama, yang aktivitasnya telah diatur oleh pejabat yang berwenang, sehingga pelaksanaannya menjadi terarah dan terorganisir dengan baik.

\section{Tujuan Penyuluhan Agama}

Tujuan penyuluhan agama Islam digunakan sebagai dasar bagi penentuan sasaran dan strategi penyuluhan, langkah-langkah operasional, mengandung luasnya cakupan aktivitas, serta ikut menentukan dan berpengaruh terhadap penggunaan materi, metode dan media yang digunakan.

Tujuan penyuluhan agama Islam adalah:

1. Tujuan hakiki, ialah menyeru kepada Allah swt (meningkatkan keimanan dan ketaqwaan).

2. Tujuan umum, ialah kebahagiaan di dunia dan di akhirat.

3. Tujuan khusus, ialah mengisi segi kehidupan itu dan memberi bimbingan bagi seluruh masyarakat menurut keadaan dan persoalannya, sehingga Islam berintegrasi dengan seluruh kehidupan manusia.

4. Tujuan urgen, ialah menyelesaikan dan memecahkan persoalanpersoalan yang ada dalam masyarakat, yakni masalah-masalah 
yang menghalangi terwujudnya masyarakat yang sejahtera lahir dan batin.

5. Tujuan insidental, ialah menyelesaikan dan memecahkan persoalan-persoalan yang terjadi sewaktu-waktu dalam masyarakat, terutama mengenai penyakit dan kepincangan dalam masyarakat, misalnya penyuapan, pemerasan dan lainlain.(Anis Purwanto, 2012)

Di lain pihak secara terperinci Thohari Munamar, dkk merumuskan tujuan bimbingan dan penyuluhan agama Islam adalah:

1. Membantu undividu mencegah timbulnya masalah-masalah dalam kehidupan keagamaan, antara lain dengan cara;

a. membantu individu menyadari fitrah manusia;

b. membantu induvidu mengembangkan fitrahnya;

c. membantu individu memahami dan menghayati ketentuan dan petunjuk Allah dalam kehidupan keagamaan;

d. membantu individu menjalankan ketentuan dan petunjuk Allah mengenai kehidupan keagamaan .

2. Membantu individu memecahkan masalah yang berkaitan dengan kehidupan keagamaan, antara lain dengan cara;

a. membantu individu memahami problema yan dihadapi;

b. membantu individu memahami keadaan dirinya dan lingkungannya;

c. membantu individu memahi dan menghayati berbagai cara untuk untuk mengatasi problem kehidupan keagamaan sesuai syari'at Islam; 
d. membantu individu menetapkan pilihan upaya pemecahan problem keagamaan yang dihadapinya.

3. Membantu individu memelihara siatuasi dan kondisi kehidupam keagamaan dirinya yang telah baik agar tetap baik atau menjadi lebih baik. (Thohari Musnamar, dkk: 1992: 144)

Dari uraian diatas dapat ketahui tujuan utama yang ingin dicapai penyuluhan agama Islam adalah terwujudnya kebahagiaan dan kesejahteraan lahir dan batin di dunia dan akhirat. Sedang tujuan khususnya, ialah nilai-nilai luhur dalam setiap segi bidang kehidupan dan pembangunan, yang berintikan nilai-nilai yang dapat mendatangkan kebahagiaan dan kesejahteraan.

Akan tetapi tujuan diatas belum dapat dipergunakan untuk mengukur keberhasilan kegiatan penyuluhan secara operasional, sebab masih sangat umum. Karenanya perlu dirumuskan tujuan operasional kegiatan penyuluhan agama, terutama menyangkut sikap dan prilaku masyarakat sebagaimana mana dikemukakan Anis Purwanto (2012), antara lain:

1. Sikap yang anti pati berubah menjadi simpati,

2. Sikap yang ragu berubah menjadi yakin.

3. Sikap yang mulai yakin berubah menjadi lebih yakin.

4. Tingkah laku yang malas dan acuh tak acuh berubah menjadi rajin dan antusias baik dalam pelaksanaan ibadah, maupun dalam kegiatan mu'amalah lainnya.

5. Dari rasa keterpaksaan berubah menjadi kesadaran dan keinsyafan pribadi serta timbul rasa memiliki.

6. Tingkah laku yang sudah rajin teratur meningkat secara kualitatif (dari kuantita ke kualita). 
7. Memelihara sikap dan tingkah laku yang sudah dihasilkan sebelumnya agar tidak mundur kembali (memelihara Kontinuitas).

8. Sikap dari semula menerima penyuluahn berubah secara kualitatif menjadi pemberi penyuluhan.

Jadi tujuan penyuluhan agama Islam ialah menyeru umat agar beriman dan bertakwa kepada Allah swt dan secara operasional adanya perubahan sikap dan prilaku dari yang negatif menjadi positif dan pasif menjadi aktif dalam hal amar ma'ruf nahi munkar sehingga umat mempunyai kesadaran yang tinggi untuk melaksanakan ajaranajaran Islam secara kaffah, untuk terwujudnya suatu kepribadian yang utuh, keluarga yang harmonis dan masyarakat yang aman, damai dan sejahtera yang diridhai oleh Allah Swt, guna mendapatkan kebahagiaan di dunia dan akhirat.

\section{Penyuluh Agama Islam}

Penyuluh Agama merupakan istilah yang ditarjamahkan dari bahasa Inggris "Religious counselor". Istilah ini mula-mula diperkenalkan oleh Wayne E Qates pada tahun 1955, ia menyatakan : There is no easy road to becoming good religious counselor any more than there is an easy to becoming any kind of effective counselor. (dalam H.M.Umar dan Sartono :1998:48)

Istilah penyuluh agama menjadi populer sejak dikeluarkannya SK Menteri Agama RI No. 79 Tahun 1985 didefinisikan Pembimbing umat Islam dalam rangka pembinaan mental, moral dan ketakwaan kepada Tuhan Yang Maha Esa, Allah SWT, serta menjabarkan segala aspek pembangunan melalui pintu dan bahasa agama. Dengan SK tersebut penyuluh agama menjadi sebutan yang dikenal luas oleh masyarakat. Karena penyuluh agama dimaksud tugasnya secara 
langsung berhadapan dengan masyarakat (umat Islam, menjadi pembimbing agama (Islam) bagi mereka.

Sebelumnya istilah penyuluh agama diperkenalkan oleh H.M Arifin pada tahun 1976 dengan bukunya Pokok-Pokok Pikiran tentang Bimbingan dan Penyuluhan Agama di Sekolah dan di Luar Sekolah. Sementara dalam dunia Pendidikan Tinggi, khususnya Fakultas Dakwah dan Komunikasi baru populer sejak adanya jurusan Bimbingan dan Penyuluhan Agama (BPA) pada tahun 1989, kemudian jurusan ini berubah namanya menjadi jurusan Bimbingan dan Penyuluhan Islam (BPI). Meskipun nama jurusannya berubah, namun essensi sama saja, yakni jurusan Bimbingan dan Penyuluhan Agama Islam,

Penyuluh agama yang berasal dari PNS sebagaimana yang diatur dalam keputusan Menkowasbangpan No. 54/KP/MK.WASPAN/9/1999, adalah Pegawai Negeri Sipil yang diberi tugas tanggung jawab, wewenang dan hak secara penuh oleh pejabat yang berwenang untuk melakukan kegiatan bimbingan keagamaan dan penyuluhan pembangunan melalui bahasa agama. Tugas pokoknya andalah melakukan dan mengembangkan kegiatan bimbingan atau penyuluhan agama dan pembangunan melalui bahasa agama.

Penyuluh Agama Islam non PNS adalah Pegawai Pemerintah dengan Perjanjian kerja yang diangkat, ditetapkan dan diberi tugas, tanggung jawab serta wewenang dan yanggung jawab secara penuh, untuk melukakam bimbingan, penyuluhan melalui bahasa agama dan pembangunan pada masyarakat melalui Surat Keputusan Kepala Kantor Kementerian Agama Kabupaten/Kota (SK Dirjen Bimas Islam 
No. DJ.III/432 Tahun 2016). Dengan standar kompetensi sebagai berikut:

1. Kompetensi ilmu Keagamaan meliputi:
a. Mampu membaca dan memahami Al Qur'an;
b. Memahami Ilmu Fiqih;
c. Memahami Hadist;
d. Memahami sejarah Nabi Muhammad saw.

2. Kompetensi Komunikasi, meliputi:
a. Mampu menyampaikan ceramah agama/khutbah;
b. Mampu memberikan konsultasi Agama

3. Kompetensi Sosial, meliputi:

a. Cakap bermasyarakat;

b. Aktif dalam organisasi keagamaan/kemasyarakatan

4. Kompetensi Moral, meliputi:

a. Berakhlaq mulia;

b. Tidak sedang terlibat dalam masalah hukum.

Penyuluh Agama Islam (PNS maupun non PNS) adalah juru penerang penyampai pesan agama Islam bagi masyarakat mengenai prinsip-prinsip dan etika nilai keberagamaan yang baik. Ia juga merupakan aparatur utama dari Kementerian Agama dalam pelaksanaan tugas membimbing umat Islam dalam mencapai kehidupan yang bermutu dan sejahtera lahir batin. 


\section{Peranan Penyuluh Agama Islam dalam Dakwah}

Untuk mengajak manusia kepada jalan Allah (Al Islam) dapat dilakukan dengan berbagai cara termasuk dengan penyuluhan, tetapi tentu saja cara-cara atau metode dakwah tersebut harus berpedoman kepada petunjuk Allah sebagaimana firman-Nya dalam surah An Nahl ayat 125 sebagai berikut:

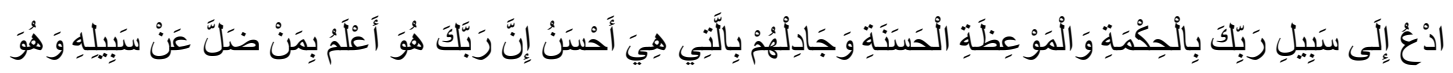

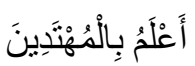

"Serulah (manusia) kepada jalan Tuhanmu dengan hikmah dan pelajaran yang baik dan bantahlah mereka dengan cara yang baik. Sesungguhnya Tuhanmu Dialah yang lebih mengetahui tentang siapa yang tersesat di jalan-Nya dan Dialah yang lebih mengetahui orangorang yang mendapat petunjuk". (Depag RI: 1996 : 421)

Syekh Muhammad Abduh menyimpulkan ayat Al Qur'an tersebut, bahwa pada garis besarnya umat yang dihadapi para pelaksana dakwah dapat dibagi atas tiga golongan yang masing-masing dihadapi dengan cara yang berbeda-beda pula, yaitu:

a. Ada golongan cerdik-cendekiawan yang cinta kebenaran dan dapat berpikir secara kritis, cepat dan arti persoalan. Mereka ini harus dipanggil dengan hikmat, yakni dengan alasanalasan, dalil-dalil dan hujjah yang dapat diterima oleh kekuatan akal mereka.

b. Ada golongan awam, orang kebanyakan yang belum dapat berpikir secara kritis dan mendalam, belum dapat menangkap pengertian-pengertian yang tinggi. Mereka ini dipanggil dengan "ma'uidzah hasanah" dengan anjuran dan didikan yang baik dengan jalan yang mudah dipahami. 
c. Ada golongan yang tingkat kecerdasannya diantara dua golongan tersebut di atas belum dapat dicapai dengan hikmat. Akan tetapi tidak sesuai pula, bila dilayani seperti golongan awam, mereka suka membahas sesuatu tetapi hanya dalam batas-batas tertentu, tidak sanggup mendalam benar. Maka demikian itu dipanggil dengan mujadah billati hia ahsan yakni dengan bertukar pikiran, guna mendorong supaya berpikir secara sehat, dan satu sama lainnya dengan cara yang lebih baik. (M. Natsir : $1981: 162$ )

Metode dakwah bil hikmah menurut pendapat Syekh Muhammad Abduh di atas, meskipun hanya ditujukan kepada kelompok cerdik-cendikiawan saja namun kata hikmah itu sendiri sering diartikan bijaksana atau kebijaksanaan, yang boleh jadi ia merasuki dua metode dakwah tersebut, bahkan dalam pengembangan berbagai metode dan teknik dakwah lainnya. Oleh karena itu M. Natsir berpendapat, bahwa istilah bil hikmah itu meliputi cara atau taktik dakwah yang diperlukan dalam menghadapi cerdik pandai, golongan awam, golongan di antara keduanya dan lain-lain golongan yang mungkin sukar untuk dimasukkan ke dalam satu dari tiga itu. (M. Natsir : $1981: 165)$

Bila dikaji secara dengan mendalam tentang cara-cara atau metode dakwah tersebut di atas, maka penyuluhan agama Islam merupakan hasil pengembangan metode dakwah yang berlandaskan metode-metode pokok dakwah tersebut, terutama metode bil hikmah dan ma'uidzah hasanah. Penyuluhan agama Islam adalah cara dakwah yang bersifat fleksibel sesuai kondisi sasaran (objek dakwah), yang kegiatannya ditekankan kepada intern umat Islam (keluarga muslim), sebagai upaya membantu sasarannya (klien) mengantisipasi 
munculnya masalah dan memecahkan masalah kehidupan mereka. Sasaran utama penyuluhan agama Islam adalah umat Islam, baik mereka yang tidak mempunyai masalah maupun mereka yang mempunyai masalah, lebih lagi menyangkut masalah keagamaan.

Tugas pokok dan fungsi Penyuluh agama Islam sebagai juru dakwah/ da'i adalah melakukan dan mengembangkan kegiatan bimbingan atau penyuluhan agama dan pembangunan melalui bahasa agama kepada masyarakat”.(KMA No.516 Tahun 2013). Tugas penyuluh tidak semata-mata melaksanakan penyuluhan agama dalam arti sempit berupa pengajian saja, akan tetapi keseluruhan kegiatan penerangan baik berupa bimbingan dan penerangan tentang berbagai program pembangunan. Ia berperan sebagai pembimbing umat dengan rasa tanggung jawab, membawa masyarakat kepada kehidupan yang aman dan sejahtera. Posisi penyuluh agama Islam ini sangat strategis baik untuk menyampaikan misi keagamaan maupun misi pembangunan. Penyuluh agama Islam juga sebagai tokoh panutan, tempat bertanya dan tempat mengadu bagi masyarakatnya untuk memecahkan dan menyelesaikan berbagai masalah yang dihadapi oleh umat Islam. Apalagi seiring dengan perkembangan ilmu pengetahuan dan teknologi, maka tantangan tugas penyuluh agama Islam sangat berat, karena dalam kenyataan kehidupan di tataran masyarakat mengalami perubahan pola hidup yang menonjol. Sebagai Penyuluh Agama Islam yang memdapatkan Surat Keputusan (SK) dari Pemerintah (Kementerian Agama), ia mendapat tugas sebagai Penyuluh Agama Islam yang mempunyai peranan sangat strategis, karena diberi tugas oleh pejabat yang berwenang untuk melaksanakan bimbingan atau penyuluh agama dan pembangunan kepada masyarakat melalui bahasa agama. 
Selanjutnya dalam Keputusan Menteri Negara Koordinator Bidang Pengawasan Pembangunan dan Pendayagunaan Aparatur Negara Nomor 54/KEP/MK.WASPAN/9/1999 disebutkan bahwa tugas pokok Penyuluh Agama adalah melakukan dan mengembangkan kegiatan penyuluhan agama dan pembangunan melalui bahasa agama. Penyuluhan agama Islam tersebut terdiri dari lima tahapan kegiatan yaitu:

a. Tahap perencanaan penyuluhan

b. Tahap pengorganisasian kegiatan penyuluhan

c. Tahap pelaksanaan penyuluhan (termasuk pelayanan konsultasi agama dan pembangunan)

d. Tahap pengawasan atau pemantauan penyuluhan

e. Tahap evaluasi dan pelaporan hasil pelaksanaan penyuluhan (Achmad Juntika Nurihsan, 2006)

Sejak semula Penyuluh Agama merupakan aparatur utama Kemanterian Agama dalam melaksanakan penerangan agama Islam di tengah pesatnya dinamika perkembangan masyarakat Indonesia. Perannya sangat strategis dalam rangka membangun mental, moral, dan nilai ketaqwaaan umat serta turut mendorong peningkatan kualitas kehidupan umat dalam berbagai bidang baik di bidang keagamaan maupun pembangunan.

Bila mencontoh teladan kehidupan Rasulullah Muhammad saw dalam kaitannya dengan pembangunan masyarakat, maka Penuluh Agama Islam bertindak menjadi social researcher (peneliti masyarakat), social educator dan community builder (A.Suryadi, 1998: 21). Sebelum melaksanakan tugas penyuluhan agama seorang Penyuluh terlebih dahulu meneliti kondisi masyarakat yang menjadi sasaran kegiatannya untuk menyusun perencaaan penyuluhan. Selanjutnya dalam kegiatannya ia bertindak sebagai pendidik yang 
mencerdaskan masyarakat dan pembangun masyarakat untuk kehidupan yang lebih baik dan sejahtera.

Dewasa ini, Penyuluh Agama Islam mempunyai peran penting dalam pemberdayaan masyarakat dan pemberdayaan dirinya masingmasing. Dengan kata lain, keberhasilan dalam bimbingan dan penyuluhan kepada masyarakat menunjukkan keberhasilan dalam manajemen diri sendiri. Penyuluh Agama Islam sebagai leading sektor bimbingan masyarakat Islam, memiliki tugas/kewajiban yang cukup berat, luas dan permasalahan yang dihadapi semakin kompleks. Penyuluh Agama Islam tidak mungkin sendiri dalam melaksanakan amanah yang cukup berat ini, ia harus mampu bertindak selaku motivator, fasilitator, dan sekaligus katalisator dakwah Islam. (Neti Sulistiani, 2014)

Penyuluh agama Islam sebagai da'i mempunyai kedudukan dan peran yang sangat penting bagi masyarakat yaitu:

1. Sebagai figur sentral yang berperan sebagai pemimpin masyarakat, sebagai imam dalam urusan agama dan kemasyarakatan serta kenegaraan dalam rangka menyukseskan program pemerintah. Dengan kepemimpinannya, penyuluh agama Islam tidak hanya memberikan penerangan dalam bentuk ucapan-ucapan dan kata-kata saja, akan tetapi bersama-sama mengamalkan dan melaksanakan apa yang dianjurkan. Keteladanan ini ditanamkan dalam kegiatan sehari-hari, sehingga masyarakat dengan penuh kesadaran dan keihklasan mengikuti petunjuk dan ajakan pemimpinnya.

2. Sebagai agen perubahan (agent of change) bagi masyarakat yakni berperan sebagai pusat untuk mengadakan perubahan ke 
arah yang lebih baik dan maju dalam segala bidang kehidupan terutama menjadi social educator karena dari sektor pendidikan inilah menjadi titik tolak perubahan masyarakat dari yang negatif menjadi positif, dari yang fasif menjadi aktif atau dari yang telah baik menjadi lebih baik lagi.

3. Sebagai motivator pembangunan bagi masyarakat. Peranan ini sangat penting karena pembangunan di Indonesia tidak semata membangun manusia dari segi lahiriah dan jasmaniahnya saja, melainkan membangun segi rohaniah, mental spiritualnya dilaksanakan secara bersama-sama. Demi suksesnya pembangunan penyuluh agam Islam berfungsi sebagai pendorong masyarakat untuk berpartisipasi aktif dalam pembangunan, berperan juga untuk ikut serta mengatasi berbagai hambatan yang mengganggu jalannya pembangunan, khususnya mengatasi dampak negatifnya.

4. Sebagai fasilitator Kementerian Agama di mana ia ditugaskan untuk meningkatkan kualitas keberagamaan umat dan penyampai misi program pembangunan, terutama bidang keagamaan. Dalam lingkungan Kementerian Agama peranan penyuluh agama Islam sangatlah penting, di mana banyak persoalan yang dihadapi oleh umat Islam menjadi tugas penyuluh Agama untuk memberikan solusi, penerangan dan bimbingan. Sehingga penyuluh agama ia dituntut untuk bersungguh-sungguh dalam menjalankan tugasnya, agar dapat mencapai tujuan yang telah ditetapkan. Peranan inilah yang sering memposisikan penyuluh agama sebagai mahkluk yang dianggap multi talenta. Oleh karena itu, penyuluh agama Islam perlu meningkatkan dan mengembangkan pengetahuan, kemampuan dan kecakapan serta menguasai berbagai strategi, 
pendekatan, dan metode/teknik penyuluhan, sehingga mampu dan siap melaksanakan tugasnya dengan penuh tanggung jawab dan profesional.

Penyuluh agama Islam sebagai seorang muslim, tugas menyampaikan penyuluhan agama ini merupakan kewajiban setiap muslim, karenanya ia harus menyadari bahwa tugas suci ini harus dapat dilaksanakan dengan sebaik-baiknya dan penuh tanggung jawab. Keberhasilan aktivitas penyuluhan tergantung pada rencana yang telah disusun oleh penyuluh, sebab dengan perencanaan yang baik penyelenggaraan penyuluhan dapat berjalan lebih terarah dan teratur rapi. Ia dituntut untuk mempersiapkan diri dengan berbagai ilmu pengetahuan, menguasai materi yang akan disampaikan, menguasai metode/teknik dan media yang akan digunakan, memahami problematika yang dihadapi oleh obyek penyuluhan untuk dicarikan jalan penyelesaiannya, dan mampu untuk memenajemen kegiatan penyuluhan agamanya dengan efektif dan efesien.

Setiap Penyuluh Agama Islam sebagai aparatur negara didalam menjalankan tugasnya sebagai penyuluh dituntut harus mempunyai kelompok binaan, maka sebelum pelaksanaan penyuluhan harus mampu mengidentifikasi potensi wilayah/kelompok sasaran dan rencana kerja operasional bimbingan/penyuluhan agama dan pembangunan, menyusun Petunjuk Pelaksanan (Juklak) dan Petunjuk Tehnis (Juknis) bimbingan dan penyuluhan agama dan pembangunan, menyusun materi penyuluhan serta mendiskusikan materi tersebut dengan sesama penyuluh agama, mengatur strategi, metode/ teknik, menyiapkan sarana dan prasana, mengadakan pemantauan dan evaluasi pelaksanaan bimbingan dan penyuluhan, dan yang terakhir mengadakan pelaporan baik mingguan, bulanan, maupun tahunan. Oleh karena itu selain penyuluh agama memiliki kemampuan dan 
kecakapan yang memadai, baik penguasaan materi penyuluhan maupun metode/tehnik penyampaian, ia juga mampu memutuskan dan menentukan sebuah proses kegiatan bimbingan dan penyuluhan, sehingga dapat berjalan sistematis, berhasil guna, berdaya guna dalam upaya pencapaian tujuan yang diinginkan.

Dari paparan tentang peranan penyuluh agama Islam sebagaimana tersebut diatas, maka jelas bahwa tugas pokok penyuluh agama Islam adalah melakukan dan mengembangkan kegiatan bimbingan atau penyuluhan agama Islam dan pembangunan melalui bahasa agama. Adapun fungsi dari penyuluh agama sebagaimana dikemukakan Anis Purwanto (2012) adalah:

1. Fungsi Informatif dan Edukatif.

Penyuluh Agama Islam memposisikan dirinya sebagai da'i yang berkewajiban mendakwahkan Islam, menyampaikan penerangan agama dan mendidik masyarakat sebaik-baiknya sesuai dengan tuntunan Al-Qur'an dan Sunnah Nabi.

2. Fungsi Konsultatif

Penyuluh agama Islam menyediakan dirinya untuk turut memikirkan dan memecahkan persoalan-persoalan yang dihadapi masyarakat, baik persoalan-persoalan pribadi, keluarga atau persoalan masyarakat secara umum. Penyuluh agama harus bersedia membuka mata dan telinga terhadap persoalan yang dihadapi oleh umat. Penyuluh agama menjadi tempat bertanya dan tempat mengadu bagi masyarakat untuk memecahkan dan menyelesaikan masalah dengan nasehatnya. Maka dalam hal ini penyuluh agama berperan sebagai psikolog, teman curhat dan teman untuk berbagi.

3. Fungsi Advokatif. 
Penyuluh Agama Islam memiliki tanggung jawab moral dan sosial untuk melakukan kegiatan pembelaan terhadap umat/masyarakat binaannya terhadap berbagai ancaman, gangguan, hambatan dan tantangan yang merugikan akidah, mengganggu ibadah dan merusak akhlak. Fungsi advokatif penyuluh agama selama ini memang belum mampu seluruhnya dapat diperankan oleh penyuluh agama, dimana banyak kasus yang terjadi di kalangan umat Islam sering tidak dapat dibela sesuai dengan porsinya.

Menurut Menteri Lukman Hakim Syaifuddin, setidaknya penyuluh mengemban tiga fungsi yang harus senantiasa terpatri. Pertama, penyuluh ialah pembimbing yang menuntun masyarakat terkait dengan agama. Kedua, penyuluh agama merupakan teladan, panutan sekaligus rujukan tempat bertanya masyarakat mengenai agama. Ketiga, penyuluh berfungsi sebagai penyambung lidah pemerintah sehingga kebijakan-kebijakan pemerintah terkait keagamaan dapat tersampaikan dengan baik di masyarakat. Musthofa Asrori (2017)

\section{Metode Pembinaan Umat}

Metode sebagai cara kerja dalam keseluruhan proses upaya pembinaan umat untuk mewujudkan Islam yang sebenarnya dalam kehidupan pribadi maupun masyarakat, diperlukan suatu rumusan cara yang bijaksana, untuk mengantarkan kepada tujuan yang akan dicapai. Secara umum metode yang digunakan penyuluh agama Islam dalam menjalankan tugasnya adalah dengan hikmah dan pelajaran yang baik dan bertukar pikiran (debat) dengan cara yang baik" (QS.An Nahl ayat 125). 
Untuk melaksanakan essensi ini, manusia dibekali oleh Allah yang berupa akal, hati, lisan dan tangan. Potensi-potensi tersebut akan dapat berperan secara aktual. Jika potensi akal dapat berfungsi secara benar (bil hikmah), akhirnya potensi potensi kemanusiaan itu dapat menghasilkan metode pembinaan keumatan sebagai berikut:

1. Metode pembinaan dengan lisan.

Metode bil lisan adalah suatu cara kerja dakwah yang lebih menunjuk kepada tata cara yang beroreintasi/mengikuti sifat dan potensi lisan dalam mengutarakan suatu cita-cita, pandangan dan pendapat tentang suatu hal. Metode bil lisan dalam penyuluhan agama Islam sering diwujudkan dalam bentuk ceramah, dialog, dan konsultasi.

\section{a. Ceramah}

Metode ceramah sebagai salah satu pengembangan dari fungsi informatif dan edukatif penyuluh agama Islam Ia merupakan pendekatan lisan (oral approach) yang paling sering digunakan adalah ceramah yakni penyampaian pesan/ materi dakwah secara lisan oleh tenaga penyuluh, sedangkan peran masyarakat sebagai penerima pesan, mendengar, memperhatikan dan mencatat informasi yang disampaikan penyuluh agama Islam.

Didalam penggunaan metode ini, diperlukan penyampaian contohcontoh kongkrit, sehingga tidak terkesan hanya wacana. Dengan harapan contoh yang disampaikan dapat memberikan motivasi tersendiri bagi para peserta penyuluhan. Seorang penyuluh harus pintar mengatur waktu didalam menyampaikan materi, sehingga tidak terkesan searah dan otoriter.

Dengan memperhatikan kegunaan, kebaikan dan kelemahan metode ceramah, penyuluh agama dapat merumuskan dan mempersiapkan 
ceramah secara efektif. Hal ini dilakukan apabila penyuluh mempunyai pemahaman yang baik tentang ceramah, antara lain dengan pemahaman tujuan ceramah, audien, penguasaan materi serta mengetahui situasi dan kondisi.

Dalam pelaksanaan penyuluhan, ceramah merupakan metode yang dominan atau banyak dipakai oleh para penyuluh agama Islam, khususnya dalam pengajian/majlis ta'lim, sehingga metode ceramah ini telah sangat membudaya, seolah-olah hanya cara ini saja yang dapat dipakai, terutama dalam masyarakat pedesaan yang perlengkapan penyuluhannya sangat terbatas dan sederhana. Maka untuk mengurangi adanya sifat monoton dan kejenuhan sasaran, seorang penyuluh dituntut agar mampu berinovasi dan berdialog dengan peserta, bahkan ditengah-tengah ceramahnya dapat diselipkan dengan ceritera-ceritera yang sudah popular dikalangan masyarakat maupun ceritera ketauladanan umat terdahulu, sebab sebaik-baik ceritera adalah ceritera yang berdasarkan Al-Qur'an dan Al-Hadits. Kemudian agar lebih komunikatif dengan jamaah, cara ini bisa diselingi dengan humor sebagai penyegar suasana, dan dapat juga diselipkan nyanyian atau kidung jawa, yang ada relevansinya dengan materi penyuluhan, dengan harapan dapat menumbuhkan daya ingat audien.

Secara oprasional cara kerja ini sering dibantu dengan teknik mau'idhah (pengajaran/penasihatan) dan mujadalah (bertukar fikiran atau tanya jawab), yang pola kerjanya secara umum ada dua pilihan prioritas:

1). Menjelaskan kekeliruan cara melaksanakan dan menata kehidupan menurut ajaran Islam (Al-Qur'an dan Al-Hadits) dan akibat-akibat kemasyarakatan (baik aspek akidah, syari'ah, ahklak). Pola ini seringa 
disebut dengan amar ma'ruf, yakni mencegah diri dari melakukan perbuatan jelek, untuk menghindari dari kerusakan dan kehancuran yang membahayakan hidup bermasyarakat.

2). Memberikan alternatif jalan keluar dengan menata ajaran dan kerangka berfikir yang jelas dan bersifat operasional. Pola ini disebut nahi munkar, yakni menekankan pada proses penyadaran individual dan masyarakat untuk meninggalkan jalan atau cara hidup yang salah, untuk menuju ke cara dan jalan hidup yang benar.

\section{Metode Dialog.}

Metode Dialog atau tanya jawab dalam pelaksanaan penyuluhan merupakan salah satu metode penyampaian dengan cara mendorong sasaran penyuluhan untuk menyatakan pendapat atau masalah yang dirasa belum dimengerti, dan penyuluh agama sebagai penjawabnya.

Metode ini sebagai tanya jawab antara jamaah dan penyuluh agama, berguna untuk mengetahui respon jamaah, mengurangi kesalahfahaman, menjelaskan perbedaan pendapat dan menerangkan hal-hal yang belum dimengerti. Metode ini efektif apabila digunakan sebagai pemecahan suatu masalah yang belum jelas dalam suatu ceramah. Metode Tanya jawab digunakan setelah ceramah atau digabung dengan metode ceramah metode ini banyak dilakukan dalam acara ceramah dan dialog. Maka metode Tanya jawab tepat apabila dilaksanakan dalam suatu ruangan atau kelas, pada acara pengajian rutin dalam kelompok binaan penyuluh agama Islam.

Semakin banyak yang bertanya semakin hidup suasana, ini berarti ceramahnya atau masalah yang dibicarakan memdapat perhatian dari audien, sehingga audien tertarik untuk banyak mengetahui. Metode ini juga dapat dipergunakan sebagai bahan evaluasi dan introspeksi 
bagi penyuluh agama sampai dimana daya serap jamaah dan untuk mengetahui sejauhmana hasil ceramahnya. Dalam pelaksanaan, pertanyaan biasanya datang dari jamaah, maka jawaban atas pertanyaan tersebut ditujukan kepada seluruh jamaah.

Tanya jawab yang dapat dinilai efektif sebagai metode penyuluhan apabila penyuluh dapat menjawab pertanyaan dari jamaahnya dengan dengan baik dan jelas, dapat menjadi solusi masalah, dan dapat menjadi tuntunan praktis bagi jamaah atau masyarakat yang menjadi sasarannya'

c. Metode Konsultasi

Metode Tanya jawab ini dapat dikembangkan menjadi metode konsultatif, yakni jamaah minta fatwa atau konsultasi kepada penyuluh tentang suatu masalah yang dihadapi, dengan harapan penyuluh dapat memberikan solusi dan alternatif pemecahan. Konsultasi bisa dilaksanakan pada saat diadakan pembinaan bersama-sama dengan jamaah yang lain (bersifat kelompok), dan bisa dilakukan secara sendiri-sendiri (perseorangan). Dalam pelaksanaan konsultasi ini penyuluh agama harus mau mendengarkan, mencatat dan mengidentifikasi masalah yang dikonsultasikan untuk kemudian dicarikan jalan keluarnya. Maka penyuluh agama harus menyiapkan blangko untuk konsultasi, baik kelompok ataupun perseorangan. Metode ini sebagai salah satu pengembangan dari fungsi konsultatif penyuluh Agama Islam.

d. Metode Diskusi

Diskusi sering sering dimaksudkan sebagai pertukaran pikiran (gagasan, pendapat, dan sebagainya) antara sejumlah orang secara. Metode diskusi membahas suatu masalah tertentu yang 
dilaksanakan dengan teratur dan bertujuan untuk memperoleh kebenaran atau solusi terhadap masalah yang tengah terjadi.

Penyuluhan agama dengan menggunakan metode diskusi dapat memberikan peluang peserta diskusi untuk ikut memberi sumbangan pemikiran terhadap suatu masalah berkenaan dengan kegiatan penyuluhan maupun materi kegiatannya. Melalui metode diskusi penyuluh dapat mengembangkan kualitas mental dan pengetahuan agama para peserta dan dapat memperluas pandangan tentang materi penyuluhan yang didiskusikan. Dengan menggunakan metode diskusi ini dapat menjadikan peserta terlatih menggunakan pendapat secara tepat dan benar tentang apa didiskusikan, dan mereka akan terlatih berpikir secara kreatif dan logis (analisis) dan objektif.

Seorang penyuluh yang hendak menggunakan metode diskusi ini sebagai metode penyuluhan agamanya, maka sebelumnya harus:

1) Memiliki pengetahuan dan keterampilan tentang teknik-teknik debat/diskusi yang baik.

2) Menguasai materi dakwah dengan sedetail-detail mungkin dan sangat menunjang bila da'i (penyuluh) sangat mengerti dan memhami tentang ajaran-ajara seta ilmu-ilmu tentangIslam.

3) Mengetahui kelebihan dan kelemahan musuh. (Asmuni Syukir, 1982: 141-144)

Penyuluhan agama dengan menggunakan metode diskusi dapat memberikan peluang peserta diskusi untuk ikut member sumbangan pemikiran terhadap suatu masalah dalam materi penyuluhan. Melalui metode diskusi da'i dapat mengembangkan kualitas mental dan pengetahuan agama para peserta dan dapat memperluas pandangan tentang materi dakwah yang didiskusikan. Dengan menggunakan metode diskusi ini dapat menjadikan peserta terlatih menggunakan 
pendapat secara tepat dan benar tentang materi dakwah yang didiskusikan, dan mereka akan terlatih berpikir secara kreatif dan logis (analisis) dan objektif. Manfaat diskusi tersebut dapat meningkatkan motivasi dan kreativitas, sikap demokratis, kritis dan argumentatif serta keterampilan dalam hal memecahkan masalah (problem solving). Dalam diskusi menyangkut materi penyuluhan agama Islam dan pembangunan Penyuluh agama dapat bertindak sebagai Penyaji (Nara Sumber) maupun Pembahas

3. Metode pembinaan dengan dakwah bil hal

Metode bil hal adalah kegiatan-kegitan dakwah yang diarahkan untuk meningkatkan kesejahteraan dan kebahagian hidup umat. Dakwah ini dilakukan melalui perbuatannya nyata dalam rangka meningkatkan upaya-upaya: mencerdaskan kehidupan masyarakat, memperbaiki kehidupan ekonomi, meningkatkan kualitas kemampuan dalam menghadapi tantangan zaman, dan member arah orientasi yang mengintegrasi iman dan takwa kepada Allah Swt dengan kemampuan integritas sebagaibagian tak terpisahkan dari kehidupan berbangsa dan bernegara. (Dirjen Bimas Islam dan Urusan Haji, 1988:12)

Dakwah bil hal lebih menekankan sedikit bicara banyak kerja (amal nyata), oleh karenanya metode ini sangat kompleks dibanding dengan penggunaan metode lainnya, sebab melibatkan pihak-pihak yang kompeten dalam bidangnya, wawasan dan ketrampilan menterjemahkan ajaran Islam dalam bentuk kongkrit serta kemampuan memahami kebutuhan dan problema umat..

Adapun cara kerja dakwah bil hal ini secara operasional sering dilakukan dengan cara melalui tindakan nyata untuk meningkatkan 
kualiatas hidup dan kesehteraan umat. Teknik operasionalnya dapat dilakukan, antara lain ((Dirjen Bimas Islam dan Urusan Haji, 1988:13):

a. Penyelenggaraan pendidikan kepada masyarakat.

b. Pemberian beberapa keterampilan agar dapat mengelola sumber daya alam yang tersedia..

c. Penyediaan modal, sebagai sarana awal untuk memulai usaha.

d. Pengaktifan/pendirian lembaga ekonomi masyarakat guna lebih meningkatkan ekonomi atau ketahanan ekonomi masyarakat (seperti Koperasi)

e. Penyelenggaraan usaha kesehatan dan peningkatan gizi masyarakat

f. Peningkatan penggunaan media informasi dan komunikasi

\section{Materi Penyuluhan Agama Islam}

Materi penyuluhan agama Islam pada dasarnya adalah seluruh ajaran agama Islam, yang sumber utamanya Al-Qur'an dan Al-Hadits. Akan tetapi harus dititik beratkan kepada pokok-pokok yang benarbenar diperlukan dan dibutuhkan oleh masyarakat sasaran. Ruang lingkup materi meliputi materi agama Islam dan materi pembangunan lintas sektoral.

\section{Materi agama Islam}

a. Materi akidah Islamiyah

Penyuluh agama Islam perlu memahami, bahwa iman tidak dapat dilihat dan diraba oleh indra, tetapi bisa dilihat dari indikatornya yaitu sikap dan prilaku (amal). Iman dapat menebal dan menipis, tergantung dari pembinaannya. Untuk itu penyuluh agama harus mengetahui materi dasar yang berkenaan dengan materi akidah Islamiyah, antara lain menyangkut: 
1) Ilmu akidah/tauhid, terutama berkenaan dengan pokok-pokok akidah Islam secara sistematis dirumuskan dalam rukun iman, yaitu:

a) Iman kepada Allah,

b) Iman kepada Malaikat-Nya,

c) Iman kepada Kitab-kitab-Nya,

d) Iman kepada Rasul-rsul-Nya,

e) Iman kepada Hari Akhirat,

f) Iman kepada Qadha dan Qadhar.

2) Sifat-sifat dan prilaku yang dapat merusak akidah

3) Perbandingan Agama (terutama tentang konsepsi Ketuhanan)

b. Materi Syariah

Penyuluh agama Islam harus menyadari bahwa kehidupan manusia di dunia ini merupakan anugerah dari Allah swt. Maka umat harus mendapatkan bimbingan sehingga didalam kehidupannya dapat berbuat sesuai dengan bimbingan Allah swt. Hidup yang dibimbing syariah akan melahirkan kesadaran untuk berperilaku yang sesuai dengan tuntunan Allah Swt. Untuk itu materi dasar yang harus dikuasai oleh penyuluh agama antara lain:

1) Fiqh Ibadah ,

2) Fiqh Muammalah

3) Fiqh Munakahat dan hukum positif tentang Perkawinan

4) Fiqh Mawaris

5) Fiqh Jinayah

6) Fiqh Siyasah

c. Materi akhlak

Penyuluh agama Islam harus memahami bahwa ahklak atau sistem perilaku ini terjadi melalui suatu konsep atau seperangkat 
pengertian tentang apa dan bagaimana sebaiknya ahklak itu harus terwujud. Sebab ahklak sebagai penyempurna keimanan dan keislaman seseorang. Pada garis besarnya akhlak Islam dibagi dalam dua bagian, yaitu;

1) Akhlak terhadap Khalik (Allah SWT), yang menifestasinya pada sikap dan prilaku beragama sebagai berikut:

a) Memuji Allah sebagai tanda bersyukur atas segala nikmat-Nya;

b) Meresapkan ke dalam jiwa kecintaan dan kasih sayang Allah kepada hamba-Nya;

c) Mengakui kekuasaan-Nya yang mutlak yang menentukan posisi manusia di dunia dan di akhirat;

d) Mengabdi hanya kepada Allah;

e) Memohon pertolongan dan hidayah hanya kepada Allah;

2) Akhlak terhadap makhluk (segala apa yang diciptakan Allah SWT)

a) Akhlak terhadap diri sendiri;

b) Akhlak terhadap keluarga;

c) Akhlak terhadap teman/masyarakat

d) Akhlak terhadap tumbuhan

e) Akhlak terhadap binatang

f) Akhlak terhadap lingkungan

d. Materi Al-Qur'an.

Penyuluh agama perlu lebih memahami bahwa Al-Qur'an adalah sebagai wahyu Allah swt, pedoman hidup dan kehidupan manusia, untuk kebahagiaan di dunia dan di akhirat. Rasulullah menjamin hidup tidak akan tersesat, apalagi berpegang teguh kepada AlQur'an dan Al-Hadits. Untuk itu penyuluh agama harus mampu 
mengajarkannya seluruh ajaran agama Islam yang bersumber AlQur'an dan Al-Hadits.

\section{Materi Pembangunan Lintas Sektoral}

Meteri Pembangunan lintas sektoral meliputi bidang, antara lain a. Materi penunjang, yaitu Pancasila, UUD 1945 dan Peraturan Perundang-undangan yang diperlukan oleh masyarakat sasaran b. Usaha peningkatan pengetahuan dan pendidikan masyakat c. Usaha peningkatan kesejahteran keluarga dan masyarakat d. Usaha perbaikan gizi keluarga (UPGK) e. Penyuluhan kesehatan masyarakat

\section{Simpulan}

Penyuluh agama Islam adalah da'i yang membimbing dan memimpin masyarakat, dalam urusan agama, kemasyarakatan dan kenegaraan dalam upaya meningkatkan kualitas kehidupan keagamaan dan kesejahteraan umat dan menyukseskan program pemerintah. Ia berperan menjadi motivator pembangunan dan agen perubahan untuk menjadikan masyarakat lebih baik lahiriah maupun batiniah untuk mewujudkan kebahagian dunia dan akhirat.Untuk itu ia dituntut untuk selalu meningkatkan kualtas pengetahuan, pengalaman dan keterampilan berkenaan dengan tugasnya agar dapat menjalankan fungsi informatif, edukatif, fungsi konsultatif, dan advokatif, terutama bagi masyarakat yang menjadi sasaran kegiatannya. .

Dalam pelaksanaan tugas Penyuluh agama Islam harus menguasai hal-hal yang berkenaan dengan materi penyuluhan 
agama Islam, metode, medianya dan logistiknya. Ia juga harus memahami kondisi masyarakat sasaran penyuluhannya, kondisi alam tempat kegiatannya, sosial budaya dan adat istiadat masyarakat. Dalam pelaksanaan proses kegiatan penyuluhan agama Islam, ia harus mampu memanajemen dengan baik mulai perencanaan, pengorganisasian, pelaksanaan, pengawasan dan evaluasi hingga pelaporannya.

\section{Daftar Pustaka}

Achmad Juntika Nurihsan, Strategi Layanan Bimbingan \& Konseling, Aditama, Bandung, 2006

Achmad Mubarok, Konseling Agama Teori dan Kasus, Bina Rena Pariwara, Jakarta, 2000

Anis Purwanto," Peranan Penyuluh Agama Dalam Pembinaan," Blog Anis

Purwanto.http: / AnisPurwanto.Blgspot.Com/2012/04/Perana nPenyuluh-Agama-Dalam Pembinaan. Html (Diakses 27 Januari 2018).

Asmuni Syukir, Dasar-Dasar Strategi Dakwah Islam, Al-Ikhlas, Surabaya, 1987.

A. Surjadi, Dakwah Islam Dengan Pembangunan Masyarakat Desa, Mandar Maju, Bandung 1998

Departemen Agama RI., Buku Panduan Pelaksanaan Tugas Penyuluhan Agama, Jakarta, 2003.

--------, Himpunan Peraturan Tentang Jabatan Fungsional Penyuluh Agama dan

Angka Kreditnya, Jakarta, 2000

Direkturat Jenderal Bimbingan Masyakarat Islam dan Urusan Haji Departeman Agama. Pedoman Penyuluh Agama Islam, Jakarta, 1995

-------, Pedoman Pembinaan Dakwah Bil-Hal, Jakarta, 1988. 
Departemen Agama RI., Al Qur'an dan Terjemahnya, Proyek

Pengadaan Kitab Suci Al Qur'an, Jakarta, 1996

Dewa Ketut Sukardi, Pengantar Teori Konseling, Ghalia Indonesia, Jakarta, 1985

H.M. Arifin, Pokok-Pokok Pikiran tentang Bimbingan dan Penyuluhan Agama di sekolah dan di Luar Sekolah, Bulan Bintang, Jakarta, 1976

H.M.Umar dan Sartono, Bimbingan dan Penyuluhan, Pustaka Setia, Bandung, 199

H. Koestoer Partowisastro, Bimbingan \& Penyuluhan. Erlangga, Surabaya, 1985

Kepres No. 87 Tahun 1999.

Keputusan Menkowasbangpan No. 54/Kep/MK.WASPAN/9/1999

Keputusan Bersama Menteri Agama dan Ka. BKN No. 574 dan 178 Tahun 1999

Keputusan Direktur Bimbingan Masyakarat Islam Kementerian Agama RI No. Dj.III/432 Tahun 2016

Munzier Suparta dan Harjani Hefni (Ed), Metode Dakwah, Prenada Mulia, Jakarta, 2009

Musthofa Asrori, Peranan Penyuluh Agama, NU Online, 27 Maret 2017 (Diakses 27 Januari 2018)

Neti Sulistiani, http/netisulistiani.Wodpress.com/Penyuluhan/Penyuluhagama/vvvvv (Diakses 27 Januari 2018)

Romly A.M. Penyuluh Agama Menghadapi Tantangan Baru, Bina Reno Pariwara, Jakarta, 2001.

Suhartini, RJ. Drs. dan Ir. Benar Simangungsong, M.Sc. Pembinaan Personil Melalui Bimbingan dan Penyuluhan, Penelrindo, Jakarta, 1989.

Syahril dan Riska Ahmad. Pengantar Bimbingan dan Konseling, Angkasa Raya, Padang, 1986

Tohari Musnamar, dkk, Dasar-Dasar Konseptual Bimbingan dan Konseling Islami, UII Press, Yogyakarta, 1992

W.J.S. Poerwadarminta, Kamus Umum Bahasa Indonesia, Balai Pustaka, Jakarta, 2003 